Guillermo Boitano* Deyvi Franco Abanto*"

Recibido: 1 de febrero de 2020

Concepto de evaluación: 31 de marzo de 2020

Aprobado: 12 de mayo de 2020

Artículo de investigación

(C) 2020 Universidad Católica de Colombia. Facultad de Ciencias

Económicas y Administrativas.

Todos los derechos reservados

* Ph.D. Candidate in Business Administration and Management. Lecturer in the area of banking and finance at the Faculty of Management Science and Economics, Universidad de Lima, Peru. Email: gboitano@ulima.edu.pe (D) https://orcid.org/0000-0001-7159-4318.

** BA in Economics, Universidad de Lima, Peru. In charge of the Economic Observatory at the Center for Studies in Banking and Finance (CEByF). Email: 20072097@aloe.ulima.edu.pe (D) https://orcid.org/0000-0002-9524-9145.

\section{Challenges of financial inclusion policies in Peru}

\begin{abstract}
The purpose of the research is to identify the main determinants of financial inclusion in Peru at the department level (without Lima) from 2010 to 2017, aiming to analyze the challenges faced by financial inclusion policies. A twostage GMM method was used to estimate a panel data model where the endogenous variable is Sarma's financial inclusion index (2008). The results indicate that bank concentration is the main variable affecting financial inclusion. At the same time, although the effect of technology is positive, it is diminishing over time due to the inefficient deployment of such technology and, in many cases, a lack of knowledge on how to use it, especially in the remote areas of Peru.

Keywords: Financial inclusion, poverty, financial education, financial exclusion, bank concentration.

JEL Classification: G21, G53, P36
\end{abstract}




\section{Desafíos de las políticas de inclusión financiera en el Perú}

\section{Resumen}

El objetivo de la investigación es identificar los principales determinantes de la inclusión financiera en el Perú a nivel departamental (sin Lima) de 2010 a 2017, con el fin de analizar los desafíos que enfrentan las políticas de inclusión financiera. Se usó un método GMM de dos etapas para estimar un modelo de datos de panel, donde la variable endógena es el índice de inclusión financiera de Sarma (2008). Los resultados indican que la concentración bancaria es la principal variable que afecta la inclusión financiera. Al mismo tiempo, aunque el efecto de la tecnología es positivo, está disminuyendo con el tiempo debido al despliegue ineficiente de dicha tecnología y, en muchos casos, a una falta de conocimiento de cómo usarla, especialmente en las zonas remotas del Perú.

Palabras clave: Inclusión financiera, pobreza, educación financiera, exclusión financiera, concentración bancaria. 


\section{INTRODUCTION}

This research aims to analyze the factors affecting financial inclusion at the department level in Peru, focusing on elements that, to date, have been considered regarding the country's financial inclusion policy. According to Soumaré, Tchana, and Kengne (2016), despite a constant economic growth, a large part of the population remains marginalized (excluded from the financial system) and does not have access to formal financial services, especially the poor, young people, and women. To address the lack of access to basic financial services, the concept of "financial inclusion" or "inclusive finance" was introduced. Thus, financial inclusion aims to attract the unbanked population to the formal financial system (Hannig \& Jensen, 2010). To fulfill the goal of this paper, a panel data model is built considering, as an endogenous variable, Sarma's (2008) financial inclusion index. Data is collected about several variables that are considered as explanatory variables of financial inclusion. The analysis is carried out from 2010 to 2017. The importance of the research lies in two facts. On the one hand, an important number of people is excluded from the benefits of participating in the financial market (SBS, 2014, 2017), which affects them in several ways: they are at the mercy of informal sources, have disadvantages in managing their daily finances, do not have the ability to build up savings or invest money to create a business to improve their welfare, and so on. In summary, these agents are not capable of breaking the vicious circle of poverty that affects the economy and social policy of a country. Such exclusion has several causes. At its roots, social exclusion, poverty, and illiteracy are considered as the most important ones. However, other factors should be considered too in solving the problem. There are macro-level factors, factors on the side of demand and factors on the side of supply. Thus, to analyze the challenges Peru must confront to reduce financial exclusion, it is necessary to know what factors influence financial inclusion and how they affect it, so that recommendations can be suggested. The main hypothesis of this research can be stated in the following way: although poverty, technology, income, education, and informality could be determinants of financial inclusion/exclusion in a certain way, in the case of Peru, the financial market structure (measured by the HHI index) is the main determinant of financial exclusion; therefore, market solutions are not alternatives to solve the problem.

The research is organized as follows: first, a theoretical framework is developed to understand what financial inclusion means and what its main causes and consequences could be, as well as to describe some of the policies applied around the world. Second, a literature review is carried out to understand empirical research 
that has been undertaken for a long time. Third, a contextual framework is presented to get familiar with the context and reality of Peru. Fourth, the methodology is explained, and the results are estimated and quantitatively interpreted. Finally, the conclusions and recommendations are elaborated.

\section{THEORETICAL FRAMEWORK}

First, it is important to have in mind a clear definition of financial inclusion and what it implies in concrete terms. Thus, financial inclusion, or the scope of banks, should be understood as the process of having a variety of formal financial services, at a fair price, in the right place, in the form and time that are required, and without inequity for all agents of the economy, especially for the at-risk groups, such as unprotected segments and low-income families (Agarwal, 2010; Hannig \& Jansen, 2010; Chakrabarty, 2011; Sarma \& Pais, 2011; Kumar, 2013; Ghosh \& Dixit, 2014; Talledo, 2015; Aparicio, Huayta \& Bohórquez, 2016; Schmied \& Marr, 2016). Similarly, the creation of an empowering atmosphere and the development of inventive financial solutions to simplify the access to financial services for a greater part of the inhabitants, by relaxing barriers (Soumaré, Tchana \& Kengne, 2016), can be added to this definition. By contrast, financial exclusion (total financial exclusion, as well as formal financial exclusion) means the absence of access of specific population sectors to suitable, low-cost, fair, secure, and reliable financial products and services offered by important formal suppliers (Wentzel, Diatha \& Yadavalli, 2016).

In the case of Peru, the National Financial Inclusion Strategy (NFIS) has adopted a concept that gathers the essential elements and considers the context of the country; thus, financial inclusion is well-defined as access to and use of valuable financial services by all population sectors (Sotomayor, Talledo \& Wong, 2018). Having the World Bank framework in mind, Jaramillo, Aparicio, and Cevallos (2013) indicate that in a country there could be found different groups of agents regarding their access and use of formal financial services: there might be agents who have access to and use the formal financial system and, at the same time, other agents that have access, but do not use it (voluntary exclusion); there might also be individuals who have indirect access to financial services because, for example, a family member (living at the same house) is a user of financial services. Nevertheless, for economic policy purposes, the interest group consists of agents who are not users of financial services because they do not have access to them, constituting what is called involuntary exclusion (Jaramillo, Aparicio \& Cevallos, 2013). 
In this way, the determinants of access and use of financial services can be seen in a supply and demand framework for financial services, the main factors being financial service prices and consumer income (Talledo, 2015). However, other nonprice factors from the supply side, such as distribution points, risk management, and institutional environment, are also important in determining access to and the use of financial services (Talledo, 2015). On the demand side, financial illiteracy, cultural barriers, lack of need, lack of awareness, and perceptions regarding individual creditworthiness may restrain financial access and usage (Talledo, 2015). Therefore, financial access (supply side: proximity and accessibility of the offer of a product or a service at a reasonable price (Sotomayor, Talledo \& Wong, 2018)) and usage (demand side: consumption (Sotomayor, Talledo \& Wong, 2018)) are closely interrelated, with access being a first stage. Given the appropriate conditions from the supply and demand sides, this would translate into the use of financial services, which would be a second stage (Talledo, 2015). Thus, following Talledo (2015), having financial service points nearby does not automatically imply their use, a decision that may be the result of voluntary or involuntary exclusion from financial services.

Regarding the importance of financial inclusion, it can be indicated, for instance, that financial institutions enable the efficient allocation of productive resources and, therefore, they can theoretically reduce the cost of capital, which helps to reduce the growth of informal sources of credit (Sarma \& Pais, 2008; Ardic, Heimann \& Mylenko, 2011; Sotomayor, Talledo \& Wong, 2018). In addition, access to appropriate financial services can significantly improve the daily management of finances (Allen, Demirguc-Kunt, Klapper \& Martinez, 2016). Moreover, the poor find it more difficult to build up savings and create assets to defend themselves against risks, as well as to invest in projects that generate income, given that they do not have access to formal financial services. As a result, interest in the growth of the financial sector has progressively promoted attention to the determinants of not only the depth, but also the scope of access, in a search for more inclusive financial systems (Hannig \& Jansen, 2010; Aparicio, Huayta \& Bohórquez, 2016).

Evidence indicates that financial systems serving low-income people stimulate growth in favor of the poor (poor people can create an economic surplus, allowing them to pay the actual costs of loans, as well as to save money) (Hannig \& Jansen, 2010; Soumaré, Tchana \& Kengne, 2016). Therefore, access to the financial system is an important tool to generate opportunities, since it allows for households to benefit from the market. In that sense, access to the financial system allows improving the economic development of a country and the well-being of its population, 
and households can reduce their vulnerability to short-term shocks, start a business, or have access to financing to get a better education (Agrawal, 2008; Jaramillo, Aparicio \& Cevallos, 2013; Ghosh \& Dixit, 2014; Talledo, 2015; Alfageme \& Ramírez-Rondán, 2016; Shihadeh et al., 2018; Sotomayor, Talledo \& Wong, 2018). Consequently, Beck (2016) determines that financial deepening has a great influence on structural transformations, poverty and income inequality reduction, especially in developing countries, so financial inclusion is a priority (Wang'oo, 2008; Kim, 2015). Finally, Rajeev and Vani (2017) emphasize that financial inclusion helps both the poor and the government, because it allows the income improvement of poor people who gain a better quality of life, and, at the same time, it makes it easier for the government to locate and direct funds to reduce poverty. Thus, greater financial inclusion positively influences financial strength (Neaime \& Gaysset, 2018).

But what causes financial exclusion? The obstacles that prevent greater financial inclusion can vary widely; they can be at the micro or macro level and be located on the demand or the supply side (Karpowicz, 2016). Table 1 summarizes the most important factors that explain financial exclusion.

As a result of financial exclusion, a series of costs and consequences are observed. At a macro level, financial exclusion can delay economic growth and spread poverty, disparity, and discrimination (Banerjee \& Newman, 1993). Burgess and Pande (2005), as cited by Kumar (2013), indicate that the effects of financial exclusion are conditional to the type and scope of the services refused. Thus, small businesses may experience problems due to a lack of access to middle-to-higher-income customers, higher cash carrying costs, and deferrals of remittances, which leads to social exclusion and increase the risk of loss due to burglary and leaving people exposed to predacious practices used by informal credit sources (Kodan \& Chhikara, 2013; Wentzel, Diatha \& Yadavalli, 2016). It can also have a high cost for individuals and financial agents in terms of missed opportunities of growth due to lack of access to credit financing and/or in the form of higher costs for basic financial transactions (Kodan \& Chhikara, 2013). Socially speaking, exclusion can cause an aggregate deficit of production or well-being and the country's growth may be affected, in addition to exacerbating social exclusion, poverty, and other related economic and social problems (it is a symptom as well as a cause of poverty) (Kodan \& Chhikara, 2013).

What mechanisms and measures have countries taken in the world to try to improve financial inclusion? According to Hannig and Jansen (2010), until the 1980s, developing countries directed public funds at subsidized rates to specific agents and 
Table 1.

\section{Causes of financial exclusion}

\begin{tabular}{|c|c|c|}
\hline Cause & Authors & Level \\
\hline Information asymmetry & Hannig \& Jansen (2010) & Macro level \\
\hline $\begin{array}{l}\text { Lack of experience of } \\
\text { financial intermediaries }\end{array}$ & Hannig \& Jansen (2010) & Supply side \\
\hline $\begin{array}{l}\text { Behavior of financial } \\
\text { intermediaries and clients }\end{array}$ & $\begin{array}{l}\text { Devlin (2009); Jaramillo, Aparicio \& Cevallos (2013); } \\
\text { Kodan \& Chhikara (2013); Talledo (2015); Karpowicz } \\
\text { (2016); Soumaré, Tchana \& Kengne (2016); Vega } \\
\text { (2017); Kabakova \& Plaksenkov (2018) }\end{array}$ & $\begin{array}{l}\text { Supply and demand } \\
\text { sides }\end{array}$ \\
\hline $\begin{array}{l}\text { Lack of income, income } \\
\text { inequality, unemployment, } \\
\text { and poverty }\end{array}$ & $\begin{array}{l}\text { Sarma \& Pais (2008); Jaramillo, Aparicio \& Cevallos } \\
\text { (2013); Kodan \& Chhikara (2013); Soumaré, Tchana \& } \\
\text { Kengne (2016); Kabakova \& Plaksenkov (2018) }\end{array}$ & $\begin{array}{l}\text { Demand side and } \\
\text { macro level }\end{array}$ \\
\hline $\begin{array}{l}\text { Costs of financial services } \\
\text { (loans and deposits) }\end{array}$ & $\begin{array}{l}\text { Jaramillo, Aparicio \& Cevallos (2013); SBS (2014); } \\
\text { Talledo (2015); Karpowicz (2016); Soumaré, Tchana \& } \\
\text { Kengne (2016); Vega (2017); Dupas, Karlan, Robinson } \\
\text { \& Ubfal (2018) }\end{array}$ & Supply side \\
\hline $\begin{array}{l}\text { Contractual and credit } \\
\text { information framework }\end{array}$ & $\begin{array}{l}\text { Jaramillo, Aparicio \& Cevallos (2013); Karpowicz } \\
\text { (2016) }\end{array}$ & Supply side \\
\hline $\begin{array}{l}\text { Sophistication of financial } \\
\text { services and products }\end{array}$ & Jaramillo, Aparicio \& Cevallos (2013); Vega (2017) & Supply side \\
\hline $\begin{array}{l}\text { Illiteracy and lack of } \\
\text { financial education }\end{array}$ & $\begin{array}{c}\text { Devlin (2009); Sarma \& Pais (2011); Kodan \& Chhikara } \\
\text { (2013); Talledo (2015); Beck (2016); Vega (2017); } \\
\text { Kabakova \& Plaksenkov (2018) }\end{array}$ & Demand side \\
\hline Informality & Talledo (2015); Vega (2017) & Macro level \\
\hline Gender, age, and ethnicity & $\begin{array}{l}\text { Kodan \& Chhikara (2013); Kabakoba and Plaksenkov } \\
\text { (2018) }\end{array}$ & Demand side \\
\hline $\begin{array}{l}\text { Physical distance and } \\
\quad \text { infrastructure }\end{array}$ & $\begin{array}{c}\text { Sarma \& Pais (2008); Kodan \& Chhikara (2013); SBS } \\
\text { (2014); Talledo (2015); Karpowicz (2016); Dupas, } \\
\text { Karlan, Robinson \& Ubfal (2018) }\end{array}$ & Supply side \\
\hline Social exclusion & $\begin{array}{c}\text { Sarma \& Pais (2011); Aduda \& Kalunda (2012); } \\
\text { Bogdan \& Totan (2013); Dupas, Karlan, Robinson \& } \\
\text { Ubfal (2018) }\end{array}$ & Macro level \\
\hline Lack of assets & $\begin{array}{l}\text { Devlin (2009); Jaramillo, Aparicio \& Cevallos (2013); } \\
\text { Kodan \& Chhikara (2013); Talledo (2015); Karpowicz } \\
\text { (2016); Soumaré, Tchana \& Kengne (2016) }\end{array}$ & Demand side \\
\hline
\end{tabular}

Source: authors' elaboration based on literature review.

controlled the range of activities for which these funds could be used. Most of the time, the funding of these loans came in the form of deposits from the public at lower interest rates, which helped to configure a scenario of financial repression, create shallow financial systems, and weaken the performance of financial institutions (Hannig \& Jansen, 2010). On the other hand, information asymmetry has been dealt with the innovation of the private sector by means of several measures, as in the case 
of banking agents (Hannig \& Jansen, 2010; Diniz, Birochi \& Pozzebon, 2011; Sinja et al., 2018), in addition to the introduction of some changes in regulatory frameworks and the provision of market infrastructure (Sarma \& Pais, 2011; Shihadeh et al., 2018; Kabakova \& Plaksenkov, 2018). In fact, Sarma and Pais (2011) mention the examples of the United States with the Community Reinvestment Act of 1997, and France with the Anti-Exclusion Law (1998).

In other countries, in addition to regulatory measures, efforts have been made to promote financial inclusion through granting microcredits to the poor and promoting electronic payments (Beck, 2016; Karpowicz, 2016), together with an improvement of education and financial innovation, including the development of technologies (Agrawal, 2008; Beck, 2016; Gabor, 2016; Akileng, Lawino \& Nzibonera, 2018). On the side of multilateral organizations, as mentioned by Jaramillo, Aparicio, and Cevallos (2013), the proposals of the World Bank (2000) promote the development of infrastructure and information technologies, as well as improvements in education, health, and market access. However, there is evidence that the development of financial inclusion depends not only on the health of financial markets, the development of microfinance (Gosh, 2013; Neaime \& Gaysset, 2018), or the easiness to open a bank account (Dupas, Karlan, Robinson \& Ubfal, 2018), but it is an entire ecosystem that includes political, social, technological, and economic spheres (Kabakova \& Plaksenkov, 2018). In many cases, beyond the financial system, limited physical infrastructure must be dealt with (particularly electricity and communications) and a better risk management system and adequate technologies must be generated to reduce high operating costs in the provision of services in remote areas with low connectivity (Alfageme \& Ramírez-Rondán, 2016).

\section{LITERATURE REVIEW}

Literature review shows that numerous studies have identified the impact of different determinants of financial inclusion (or exclusion). For instance, Sarma and Pais (2011) find that the proportion of non-productive assets is inversely related to financial inclusion, while the ratio of capital assets is negatively associated with financial inclusion, so that when this ratio is high, financial agents have a tendency to be more careful about accepting the financially excluded. In the same way, they demonstrate that foreign ownership in the banking sector has a negative effect, while government ownership does not have a noteworthy effect. In addition, Sarma and 
Pais (2011) also state that interest rates do not seem to be considerably linked to financial inclusion.

On the other hand, Bogdan and Totan (2013) conclude based on their results that the variables of growth rate, unemployment, inflation, and real income index significantly influence financial inclusion. Similarly, Anzoategui, Demirgüç-Kunt and Martínez (2014) investigated the impact of remittances on financial inclusion. The authors have found that remittances have a positive impact on financial inclusion, but they have no effect on credits.

Likewise, Allen, Demirguc-Kunt, Klapper and Martinez (2016) suggest that greater financial inclusion is associated with lower costs of financial services (account maintenance), closeness to financial intermediaries, having stronger legal rights, and more politically stable settings. They also mention, however, that policy effectiveness to stimulate inclusion fluctuates according to the distinctiveness of persons.

On the other hand, Sharma (2016) suggests a positive relationship between economic growth and several features of financial inclusion (bank penetration, possibility to obtain banking services, and the use of them in terms of deposits). Likewise, the study shows a bidirectional interconnection between geographic scope and economic development, in addition to a unidirectional causation between the number of deposits/loan accounts and GDP. Similarly, Talledo (2015) shows that available and affordable service points in terms of shorter travel time to a financial service point predict a higher probability of formal access to credit and lower probability of requesting an informal loan. In addition, higher educational attainment, employment, marriage, number of dependents, and a higher level of welfare are positively associated with the probability of applying for a loan, especially in a formal institution. Moreover, Talledo (2015) adds that those who perceive formal credit costs and process length as the most important factors in loan application are more likely to ask for a formal loan, which may imply a higher knowledge that allows them to better compare their available options and choose the least expensive and fastest one.

Soumaré, Tchana, and Kengne (2016) conclude that financial inclusion is positively affected by the following individual characteristics: level of secondary or higher education, working age group, high-income quintiles, urban residency, fulltime employment, being married, smaller household size, and confidence in financial institutions. They also mention that gender is a robust factor of access to financing, and the size of households is a significant determinant too. Likewise, Wentzel, Diatha, and Yadavalli (2016) identify eight demographic factors that earlier researches 
emphasized as probably related to financial exclusion. These factors were gender, age, the main source of income, state of home ownership, marital status, highest educational level reached, number of dependents supported by the respondent, and geographic location. Alfageme and Ramírez-Rondán (2016) find a positive relationship between income, education, and age, and a negative relationship between those who live in rural areas and in extreme poverty.

In their review, Thoene and Turriago-Hoyos (2017) suggest that financial education is the most critical variable in the examination of financial inclusion and social improvement. Also, Rajeev and Vani (2017) point out that information and communications technologies solutions help banks to capture customer data and facilitate the service of transactions and remote information, helping to reduce the problem of information asymmetry. On the other hand, Wang and Guan (2017) indicate based on their results that a person's income, education, and the use of communication equipment are critical factors explaining the intensity of financial inclusion, while financial depth and banking health are the main determinants. In their study, Park and Mercado (2018) point out that per capita income, rule of law, and demographic characteristics considerably affect inclusion. The results show that financial inclusion significantly correlates with lower levels of poverty and income inequality. Similarly, Iqbal and Sami (2017) establish that there is a positive and significant relationship between the number of bank branches and the ratio of credit/deposits to GDP, unlike the growth of ATMs whose impact is not significant. Subsequently, Lopez and Winkler (2017) demonstrate that credit activities in rural areas can be structured to become sustainable and that institutions with a greater emphasis on rural costumers cannot achieve the same economies of scale and productivity than those focusing on non-rural areas; consequently, the development of financial inclusion in rural areas is harder than in non-rural ones.

In the same direction, Chandwani and Kulkarni (2018) conclude that gaps in digital literacy and financial education must be overcome in order to obtain the desired result on financial inclusion. On the other hand, Sotomayor, Talledo and Wong (2018) point out that a good economic position of the individual and, therefore, a better ability to pay, such as higher income, physical assets, saving money, and having internet services, help access the financial system. They also point out that other variables, such as higher educational levels, being married, and, in the case of small urban and rural segments, knowledge of how to calculate a simple interest rate would also facilitate access to credit. They add that gender does not imply differences in access to credit, and that, in rural segments, income does not seem to 
affect the ownership or use of deposit accounts. In the same way, the population's perceptions about banks and the criteria used when requesting financial services also seem to influence financial inclusion.

In conclusion, the review of literature shows that there are different factors that can positively or negatively affect financial inclusion. However, there are some commonalities among the studies. Thus, there are demand side factors that determine the degree of financial inclusion of an economy, which focus on the characteristics of individuals or agents; these include, among others, income, employment status, education level, gender, culture, the amount of assets held, the degree of formality. But there are also supply side factors that have various effects on inclusion or exclusion, such as distance from service points, technology and the use of it to facilitate access and information collection and to realize transactions, the cost of financial services, the transparency and simplicity of financial products, bank concentration, among others. The analysis also shows that macroeconomic factors as well could help improve the degree of financial inclusion of a country. These macro-level factors are the degree of development of physical and technological infrastructure, regulations and their applicability, the informality of the economy, the degree of economic and social inequality, the proportion of urban development compared to rural growth, population density, economic growth, and poverty level.

\section{THE CASE OF PERU}

Peru has implemented a series of joint efforts between the public and private sectors in order to tackle the problem of low access and use of financial services in general, which resulted not only in the promulgation of the Electronic Money Law, but also in the establishment of a National Financial Inclusion Strategy (NFIS) (Vega, 2017). Thus, in 2014, the Inter-Institutional Committee on Financial Inclusion was implemented to define the NFIS, and seven key areas of interest were identified: digital payments, savings, credits, insurances, consumer protection, financial education, and vulnerable groups (Vega, 2017). Two particular situations can be found in Peru. First, the main banks dominate approximately $80 \%$ of the loan and deposit market, while the rest of the banks operating in the market use the policies applied by the first four banks as guides for their course of action (Pizarro Aranguren \& Caballero Muñiz, 2009). This concentration affects financial inclusion. Second, the high degree of informality in the economy limits, deviates or prevents people's access to the banking system, which, by its nature and in accordance with local and international regulations (Basel 
Agreement), requires reliable tools for analyzing the payment capacity of users (as for the potential recovery of the credits granted), while maintaining a high standard of information quality, as well as for the classification of credits and debtors. This prevents most of the actors in an informal economy to have access to credit, thus presenting problems of adverse selection as a result of asymmetric information (Pizarro Aranguren \& Caballero Muñiz, 2009). In this context, the State's commitment to the process of improving financial inclusion is reflected precisely in the activities carried out by the Multisectoral Commission for Financial Inclusion to design and establish three basic pillars: use, access, and quality of financial services, as indicated in the NFIS (Alfageme \& Ramírez-Rondán, 2016). Thus, actions have been carried out to expand infrastructure and digital technology, as well as to encourage, through new financial products, greater competition to reduce costs (for example, the Mobile Wallet or BIM), estimating that by 2020 approximately two million of new users could be incorporated into the market (Alfageme \& Ramírez-Rondán, 2016). In parallel, the Superintendency of Banking (SBS), the Ministry of Education (MINEDU), and representatives of the civil society are carrying out several projects aimed at the development of a financial education policy called the National Financial Education Plan (NFEP) (García et al., 2013). One of the most successful policies launched by the SBS regarding financial inclusion during the last decade was the promotion of retail agents as financial agents that work in either fixed or mobile establishments (Aparicio, Huayta \& Bohórquez, 2016). In fact, as mentioned by Mas and Almazán (2011), and as cited by Aparicio, Huayta, and Bohórquez (2016), having retail agents help financial institutions in terms of decongesting branches, developing businesses in new locations, and creating a transaction-based proposal targeting poorer segments, refocuses branches on selling financial products rather than handling cash and fills a competitive vacuum that others might fill otherwise. Thus, in Peru, the regulatory framework proposed by the SBS has permitted to expand the coverage of financial services to individuals and enterprises that previously had no access to basic financial services, especially in geographical areas where the presence of the financial system was minimum or null (Aparicio, Huayta \& Bohórquez, 2015). However, although it is important to acknowledge improvements in the process of financial inclusion in Peru, the levels of financial access and usage are not the same across the country, since there are significant differences between Lima and the rest of the departments, as well as in comparison to the countries of the region and to developed countries (Jaramillo, Aparicio \& Cevallos, 2013; Talledo, 2015; Aparicio, Huayta \& Bohórquez, 2016). 
It is important to highlight some of the advances in the financial inclusion process in Peru. According to the SBS (2019), between June 2014 and June 2019, the number of banking agents increased from 313 to 960 per 100,000 adults nationwide. This growth was due to the expansion of infrastructure and a greater degree of sharing of agents among banks. On the other hand, regarding the use of financial services, the SBS (2019) indicates that during the last five years, 1.2 million debtors were incorporated into the financial system, reaching 7.1 million persons with outstanding loans. In the same period, 668,000 micro and small entrepreneurs were incorporated into the financial system, reaching about 2.6 million debtors as of June 2019. In this process, microfinance entities have played an important role, since they have a greater participation in low-income segments, unlike traditional banks. Despite these improvements, the percentage of the adult population with credit increased from 31\% in June 2014 to only 34\% in June 2019. In fact, globally, 69\% of adults have a bank account or are using mobile money apps (World Bank, 2019). At the same time, there are important differences between the degree of progress in Lima with respect to the provinces. Thus, while in the capital $51 \%$ of adults had an outstanding loan by 2019, in provinces the same figure runs from as low as $11 \%$ (Huancavelica) to as high as 45\% (Arequipa) in the same time spam (SBS, 2019).

\section{METHODOLOGY AND RESULTS}

Based on the above, it is easy to understand the need to measure financial inclusion in order to monitor its levels, to get a deeper understanding of factors explaining financial inclusion (or exclusion), and to evaluate the impact of the applied policies (Hannig \& Jansen, 2010). In that sense, methodologically speaking, this research examines 23 Peruvian departments during 2010 and 2017, without considering Lima. The central government applies national policies of financial inclusion in these departments at horizontal levels, and although there are differences among them at the socio-economic level, the tendency goes in the same direction in search of the well-being of the population.

To develop the present research, a panel data model is proposed where the endogenous variable is financial inclusion, measured by Sarma's index. Sarma (2008) uses three factors to explain financial inclusion in a single index. In his methodology, information derived from several dimensions of financial inclusion is captured in a single digit that fluctuates between zero and one, where zero indicates complete financial exclusion and one denotes complete financial inclusion. Regarding the 
above mentioned three dimensions, Sarma (2008) indicates that these are: i) bank penetration (dimension 1): an inclusive financial system must have as many users as possible, that is, an inclusive financial system must penetrate widely amongst its users (financial intermediation ratios of deposit and credit) ( $\rho$ ); ii) availability of banking services (dimension 2): the services of an inclusive financial system should be readily available to its users. The availability of services can be indicated by the number of bank outlets (per 100,000 inhabitants) and/or by the number of ATMs per 100,000 people, or the number of bank employees per customer $(\alpha)$; and iii) usage (dimension 3): in some apparently highly-banked countries, a number of people with a bank account make very little use of the services offered. These people are called "under-banked" or "marginally banked" (number of debtors/adult population (\%) or holding of accounts) ( $\mu$ ). These three dimensions result in the indicator of financial inclusion or IFI, using the following calculation:

$$
\mathrm{IFI}=1-\sqrt{\frac{(1-\rho)^{2}+(1-\alpha)^{2}+(1-\mu)^{2}}{3}}
$$

The results of the financial inclusion index applied to the departments of Peru are presented in Annexes 1 to 3, showing that the department with the highest inclusion is Arequipa and the lowest is Huancavelica for the period under analysis.

After calculating Sarma's index, a panel model is built to incorporate the explanatory variables of financial inclusion/exclusion to evaluate them as determinants. The estimation is made using the two-stage generalized method of moments (GMM). GMM is used when there exist endogeneity problems. Thus, under this method, the $X$ variables must be explained by $Z$ instruments. The consistency of the model is determined under the assumptions of $(\operatorname{cov}(Z, \mu)=0)$ and $(\operatorname{cov}(Z, X) \neq 0)$, then, if these assumptions are met, the model is efficient. Furthermore, the number of $\mathrm{Z}$ instruments is greater than the number of endogenous $\mathrm{X}$ variables. To validate the use of the instruments, the Hansen test is used to determine the validity of over-identification, where the p-value must indicate that the null hypothesis should be accepted, which refers to the model as correctly specified if it complies with:

$$
E\left\{Z_{i} u_{i}(\beta)\right\}=0
$$

Another determining factor for using two-stage GMM is derived from the fact that it is resistant to heteroskedasticity. In the case of financial inclusion, there is a heterogeneous effect in the different departments of Peru, as a result of differences in economic and social development. This heterogeneous effect is assumed by the 
two-stage GMM method. On the other hand, the data used limits the application of a dynamic panel as a result of the short-term availability of information for technological variables, which are Mobile Broadband Subscription and Mobile Banking Applications, available since 2010. This supports the use of a micro panel and, therefore, a non-dynamic study ( $\mathrm{T}>\mathrm{N}$ ) is carried out. In this way, the specified model is as follows:

Financial Inclusion Index $=B_{0}+$ Banking Concentration $_{i t}+$ Unsatisfied Basic Needs $_{i t}$

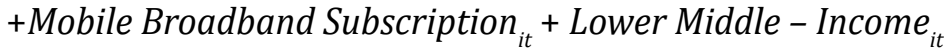
+ Upper Middle - Income ${ }_{i t}+$ Illiteracy Rate $_{i t}+$ Secondary Education $_{i t}$ + Informal Micro and Small Enterprises ${ }_{i t}+$ Mobile Banking Applications $_{i t}+\alpha_{i}$ $+\mu$ it Instruments (Housing Characteristics + Overcrowding +Higher Education + Health Insurance+Pension Funds + Internet Access -Households + Informal Employment + Investing in Early Childhood Education +Investment in Primary Education +Investment in Secondary Education)

The definition of variables as well as the expected signs are shown in Table 2.

The model aims to incorporate some of the specific variables mentioned in the Peruvian guidelines for financial inclusion, as well as some of the variables discussed in the literature review not only to analyze the effectiveness of managing such variables under the selected policy, but also to gain additional knowledge about the limitations and challenges faced by the entities in charge of fighting financial exclusion. Thus, the use of mobile technologies (specifically, access to mobile internet, 4G network, the use of smartphones and mobile banking apps) are promoted in order to improve the scope and use of the financial system. For that reason, the model considers the following variables: Mobile Broadband Subscription and Mobile Banking Applications. On the other hand, it is said that a competitive financial system could help reduce financial exclusion because banks would try to reach unattended population segments in order to increase their market share and to get a better market position, while, at the same time, improving financial services and reducing costs in favor of clients. So, the model takes into consideration the variable Bank Concentration. Similarly, education is said to be a key variable to improve financial inclusion, thus Illiteracy Rate and Secondary Education are included in the model. As mentioned in the literature, the level of income and poverty degree are important factors because they imply less economic capacity to successfully pay back a loan. It is important to mention that, in order to qualify costumer creditworthiness, banks 
Guillermo Boitano • Deyvi Franco Abanto

Table 2.

\section{Definition of variables and expected signs}

\begin{tabular}{|c|c|c|c|c|}
\hline Variable & Definition & Source & $\begin{array}{l}\text { Expected } \\
\text { sign }\end{array}$ & Supported by \\
\hline $\begin{array}{l}\text { Banking } \\
\text { Concentration } \\
\text { (HHI) }\end{array}$ & $\begin{array}{l}\text { It is a measure of concentration. The } \\
\text { Herfindahl-Hirschman Index (HHI), } \\
\text { defined as the sum of the squared market } \\
\text { share of each bank in the system, is used. } \\
\text { The HHI accounts for the market share } \\
\text { of all banks in the system and assigns a } \\
\text { larger weight to the biggest banks. }\end{array}$ & $\begin{array}{c}\text { SBS } \\
(2019)\end{array}$ & Negative & $\begin{array}{l}\text { Owen \& Pereira (2016); } \\
\text { Chauvet \& Jacolin (2017) }\end{array}$ \\
\hline $\begin{array}{l}\text { Unsatisfied } \\
\text { Basic Needs }\end{array}$ & $\begin{array}{l}\text { Proxy for household poverty. Number } \\
\text { of people (as a \% of the total) who have } \\
\text { two or more unsatisfied needs, such as } \\
\text { access to housing, health services, and } \\
\text { education, for instance. }\end{array}$ & $\begin{array}{l}\text { INEI } \\
(2019)\end{array}$ & Negative & Park \& Mercado (2018) \\
\hline $\begin{array}{c}\text { Mobile } \\
\text { Broadband } \\
\text { Subscription }\end{array}$ & $\begin{array}{l}\text { Number of smartphones with connection } \\
\text { to mobile internet service by department. }\end{array}$ & $\begin{array}{c}\text { INEI } \\
(2018 b)\end{array}$ & Positive & $\begin{array}{l}\text { Kumar, Pal \& Pal (2018); } \\
\text { Mushtaq \& Bruneau } \\
\text { (2019), Seng (2019) }\end{array}$ \\
\hline $\begin{array}{l}\text { Lower } \\
\text { Middle- } \\
\text { Income }\end{array}$ & $\begin{array}{c}\text { Categorical variable measuring the } \\
\text { income level of inhabitants. This is the } \\
\text { lower quantile (between S/. } 400 \text { to S/. } \\
700 \text { ). }\end{array}$ & $\begin{array}{c}\text { INEI } \\
(2018 \mathrm{a})\end{array}$ & Positive & $\begin{array}{c}\text { Sarma \& Pais (2011); } \\
\text { Zins \& Weill (2016); Seng } \\
\text { (2019) }\end{array}$ \\
\hline $\begin{array}{l}\text { Upper } \\
\text { Middle- } \\
\text { Income }\end{array}$ & $\begin{array}{l}\text { Categorical variable measuring the } \\
\text { income level of inhabitants. This is the } \\
\text { upper quantile (between S/. } 750 \text { to S/. } \\
1500 \text { ). }\end{array}$ & $\begin{array}{c}\text { INEI } \\
(2018 \mathrm{a})\end{array}$ & Positive & $\begin{array}{c}\text { Sarma \& Pais (2011); } \\
\text { Zins \& Weill (2016); Seng } \\
\text { (2019) }\end{array}$ \\
\hline Illiteracy Rate & $\begin{array}{l}\text { It is the percentage of people ( } 15 \text { years } \\
\text { old or older) who cannot read or write. }\end{array}$ & $\begin{array}{c}\text { INEI } \\
(2018 \mathrm{c})\end{array}$ & Negative & $\begin{array}{c}\text { Burgess \& } \\
\text { Pande (2005); Beck, } \\
\text { Demirgüç-Kunt \& Levine } \\
(2007)\end{array}$ \\
\hline $\begin{array}{l}\text { Secondary } \\
\text { Education }\end{array}$ & $\begin{array}{l}\text { Secondary school completion rate } \\
\text { measured as a } \% \text { of the total (age group } \\
25 \text { to } 34) .\end{array}$ & $\begin{array}{l}\text { MINEDU } \\
(2020)\end{array}$ & Positive & $\begin{array}{l}\text { Zins \& Weill (2016); Léon } \\
\text { \& Zins (2020); Kumar, Pal } \\
\text { \& Pal (2018); }\end{array}$ \\
\hline $\begin{array}{l}\text { Informal } \\
\text { Micro } \\
\text { and Small } \\
\text { Enterprises }\end{array}$ & $\begin{array}{l}\text { Number of MSBs based on information } \\
\text { taken from ENAHO. The size of the } \\
\text { company is defined according to the } \\
\text { range of workers: micro enterprises with } \\
\text { up to } 10 \text { workers and small businesses } \\
\text { with } 10 \text { to } 100 \text { workers. }\end{array}$ & $\begin{array}{l}\text { PRODUCE } \\
(2020)\end{array}$ & Negative & ILO (2016) \\
\hline $\begin{array}{l}\text { Mobile } \\
\text { Banking } \\
\text { Applications }\end{array}$ & $\begin{array}{c}\text { A dummy variable to incorporate the } \\
\text { expansion of financial services through } \\
\text { mobile banking applications ( } 1 \text { if year } \\
\text { is equal to or greater than } 2014 \text { and } 0 \\
\text { before } 2014 \text { ) }\end{array}$ & $\begin{array}{c}\text { BCP } \\
(2014)\end{array}$ & $\begin{array}{l}\text { Negative/ } \\
\text { Positive }\end{array}$ & $\begin{array}{l}\text { Klein \& Mayer (2011); } \\
\text { Ozili (2018); Fernández, } \\
\text { Llanes, López- } \\
\text { Moctezuma, Rojas \& } \\
\text { Tuesta (2014) }\end{array}$ \\
\hline
\end{tabular}

Source: authors' elaboration. 
take into consideration not only the agent's level of income, but also if he or she has assets by their own. Thus, the model considers Unsatisfied Basic Needs, Lower Middle-Income, and Upper Middle-Income as proxies for poverty and income level. Finally, informal economy is mentioned as a negative factor for financial inclusion because, among other things, those operating under informality do not have a clear and complete information (information asymmetry) about how much money they get and what kind of assets they have, which affects their creditworthiness evaluation. Consequently, the number of Informal Micro and Small enterprises is considered.

The model was estimated in Stata, and the results are presented in Annex 4. Estimated signs are as expected. At the level of individual variables, Bank Concentration has a negative and significative impact on financial inclusion. In the case of technology, the results are contradictory. On the one hand, the variable Mobile Broadband Subscription has a positive impact, which demonstrates the relevance of using smartphones that allow internet access to bank sites and their applications. On the other hand, when considering the Mobile Banking Applications variable, the impact is negative. This could be explained from three perspectives: lack of training in the use of the new technology, lack of confidence in the transaction's security, and degree of deployment of technology in provinces. Thus, for example, Ozili (2018) analyzes the development of digital finance in emerging economies, indicating that digital finance does not serve people who do not have a mobile phone or other digital devices; similarly, the introduction of the technology is important because a forced introduction can lead to voluntary financial exclusion if population is not ready for using it. Additionally, Banerjee, Brezza, Duflo and Kinnan (2019) indicate that the fact that efficient technology is available does not eliminate the need to evaluate whether the credit subject is talented or experienced or he or she is efficiently managing his or her business. Therefore, beside evidence from these two studies, it is important to highlight that the mere introduction of mobile applications and the development of $4 \mathrm{G}$ networks nationwide are not enough to have a significant impact on the reduction of financial exclusion. Following with the results, poverty (Unsatisfied Basic Needs) has a negative impact on financial inclusion, reaffirming the fact that, beside the income level, having unsatisfied needs influences asset ownership and, therefore, the capacity to enter into the financial market. In the same way, income has a positive effect on financial inclusion: the higher the income, the greater the opportunity to get into the financial market. When dealing with education, none of the variables Secondary Education and Illiteracy Rate are significant, although they satisfy what was proposed by Sotomayor, Talledo, and Wong (2018). It is important to mention 
that the observed results are due to the fact that illiteracy has been reduced in Peru from $8 \%$ in 2010 to $6 \%$ in 2017. Finally, informality, measured by the number of micro and small informal businesses, is not significant either. The reason for such result could be the fact that between $80 \%$ to $84 \%$ of informal companies use internal funds, friends and family funds, and informal lenders to finance working capital and investments (ILO, 2016), although informality impacts negatively financial inclusion.

\section{CONCLUSIONS}

The market structure of the financial system does not help to reduce financial exclusion due to its high degree of concentration. That is, the market is dominated by four institutions whose general policies and regulations prevent them from reaching unattended segments, constituting (as Stiglitz and Weiss (1981) mention it) a creditrationing regime. In this way, traditional banks tend to attend to the usual segments for which they have certain standardized products that can be offered without major changes since these users already know these products and are in accordance with them. These institutions, due to information asymmetry and economies of scale, find it complicated, and even tedious, to change their operating strategies to attend to the excluded. In this context, microfinance institutions and, in recent years, Fintech have partly become substitutes in offering attention to these segments. From this point of view, it is recommended that the country's financial inclusion policies take into account and encourage the existence and operativity of these two agents (besides banking agents) given that, despite having a small participation in the financial market as a whole, they have demonstrated greater capacity to attend to the excluded. It should be mentioned that, to date, Peru does not have a law for Fintech, so it is necessary to consider the participation of these entities in the market to be able to promote any type of regulation.

In the case of technologies, the dichotomy observed in the results should draw the attention of the Peruvian authorities to the need to improve technology development and deployment at the regional level along with the development of general and supportive infrastructure, which can be used by private entities to develop more apps for smartphones and have more access points, taking advantage of the high penetration of mobile phones. But authorities must also consider the necessary training and learning process through which the users of these applications must necessarily pass, without forgetting that one of the relevant aspects is to ensure user protection and safety when performing a transaction. In the same way, authorities 
should analyze incentives for the development and use of technologies by financial institutions for the information gathering process, which should be complemented with information that government entities can obtain in their own process of market regulation and monitoring. In that sense, the promotion of sharing (either applications or agents) between financial institutions is important because it reduces the efforts and costs of gathering information and doing transactions, which constitutes an alternative that could help in the process of incorporating new segments into the financial system.

Perhaps one of the most important challenges faced by authorities responsible for promoting financial inclusion is poverty reduction. There are two basic aspects here: income improvement and the promotion of property titles. In the first case, this implies the need, in a market economy, to look for mechanisms that guarantee that the Peruvian economy grows above $3 \%$ annually, while ensuring an adequate redistribution of income and equal opportunities. These last two aspects could be achieved based on tax policies that allow broadening the taxpayer base, thereby increasing tax revenues that would, at the same time, help to improve basic aspects such as health, education, and housing, to name a few examples. Regarding property titles, it is necessary to formalize the property of the less favored. For example, farmers who do not own their land titles should own them. It is important to clarify that this measure does not end with the mere delivery of property titles; instead, property is only the first element to enter into the market. What comes after is perhaps the most complex and delicate work, which is to promote associativity and entrepreneurship based on appropriate technical and economic advice. An example of this is the Inclusive Rural Business Development Program (PRIDER for its acronym in Spanish) of the Development Finance Corporation (COFIDE for its acronym in Spanish), whose objectives are aligned with the United Nations Sustainable Development Objectives, and which also incorporates financial inclusion objectives through the Credit and Savings Union (UNICA). Unfortunately, little information is available to conduct a deeper analysis of the results obtained in the fight against poverty and financial and social exclusion.

In addition, regarding education, authorities should focus not only on the reduction of illiteracy, but also on the improvement of education quality and what is called financial education. On the other hand, improving the quality of education is a national objective that is dependent on the central government, thus its promotion is tied to the general objectives of each government. Improvements have been made based on policy measures aimed at promoting a better quality of education (training and evaluation of teachers, creation of the Superintendent of Higher Education, etc.), but these initiatives 
are still limited. Perhaps the most important point would be to reach a national agreement so that, regardless of who is in government, the budget of the education sector is incrementally and significantly increased to improve both education infrastructure and teacher knowledge. In this context, the national educational curriculum should, in addition, concentrate more efforts towards the financial education of students who, in the future, would be users of the financial system. This financial education should focus on introducing basic instruments, such as interest rate calculation, as well as the most important concepts used in the economic-financial activity, in order to improve the understanding of abstract concepts of common people.

In the case of informality, the development of technology and its use in data collection, the extension of the tax base, sustained economic growth, financial education, and poverty reduction will help to reduce informality, together with specific measures that could be implemented for this purpose. For this reason, no further analysis is made in this regard.

All the above must be understood as a joint effort and not isolated policies that come from different actors within the Peruvian economy with the capacity and decision-making power to face the challenge of reducing financial exclusion. However, the central aspect in this whole scheme, following Mader (2017), must be to maintain the focus on the fight against poverty and inequality as the first objective to overcome exclusion.

The possibility is open for future research that analyzes the relationship between poverty and financial exclusion, where it is possible to evaluate aspects derived only from the demand side that are necessary to know to break the inertia of not using the financial system, as well as to assess the work carried out by microfinance institutions, Fintech, and development programs such as COFIDE.

\section{REFERENCES}

1. Aduda, J., \& Kalunda, E. (2012). Financial Inclusion and Financial Sector Stability with Reference to Kenya: A Review of Literature. Journal of Applied Finance $\mathscr{E}$ Banking, 2(6), 95-120.

2. Agarwal, A. (2010). Financial Deepening, Financial Inclusion: Challenges and Opportunities. The 23rd Skoch Summit.

3. Akileng, G., Lawino, G. M., \& Nzibonera, E. (2018). Evaluation of determinants of financial inclusion in Uganda. Journal of Applied Finance and Banking, 8(4), 47-66. http://www.scienpress.com/Upload/JAFB\%2FVol\%208_4_4.pdf 
4. Alfageme, A., \& Ramírez-Rondán, N. (2016). Acceso a servicios financieros de los hogares en el Perú. Working Papers 2016-015. Lima: Banco Central de Reserva del Perú.

5. Allen, F., Demirguc-Kunt, A., Klapper, L., \& Martinez, M. (2016). The foundations of financial inclusion: understanding ownership and use of formal accounts. Journal of Financial Intermediation, 27, 1-30.

6. Anzoategui, D., Demirgüç-Kunt, A., \& Martínez, M. (2014). Remittances and Financial Inclusion: Evidence from El Salvador. World Development, 54 (C), 338-349. https://doi. org/10.1016/j.worlddev.2013.10.006

7. Aparicio, C., \& Huayta, K., (2015). Using electronic money through the mobile phone as the key instrument to improve financial inclusion in Peru: A set of recommendations to generate the desired outputs. DT/02, Lima: SBS.

8. Aparicio, C., Huayta, K., \& Bohórquez, D. (2016). Access to Financial Services through Retail Agents and Household Expenditures: Evidence from Peru. Journal of Financial Issues SBS, 12(1), 1-26.

9. Ardic, O. P., Heimann, M., \& Mylenko, N. (2011). Access to financial services and the financial inclusion agenda around the world: a cross-country analysis with a new data set. Policy Research working paper, WPS 5537. Washington, DC: World Bank.

10. Banco de Crédito del Perú (BCP). (2014). Reporte anual 2014. BCP: Lima. https://ww3. viabcp.com/Connect/ViaBCP\%202017/Personas/Relaciones\%20con\%20Inversionistas/ Informaci\%C3\%B3n\%20financiera/Memoria\%20BCP\%202014.pdf

11. Banerjee, A., \& Newman, A. (1993). Occupational Choice and the Process of Development. Journal of Political Economy, 101(2), 274-98. https://www.jstor.org/ stable/2138820

12. Banerjee, A., Breza, E., Duflo, E., \& Kinnan, C. (2019). Can Microfinance Unlock a Poverty Trap for Some Entrepreneurs? NBER Working paper No. w26346.

13. Beck, T. (2016). Financial Inclusion: Measuring progress in measuring. Paper presented at the $4^{\text {th }}$ IMF Statistical Forum: Lifting the Small Boats: Statistics for Inclusive Growth. Nov. 17-18, 2016, Washington, D.C.

14. Beck, T., Demirgüç-Kunt, A., \& Levine, R. (2007). Finance, inequality and the poor. Journal of Economic Growth, 12(1), 27-49. https://doi.org/10.1007/s10887-007-9010-6

15. Bogdan, B., \& Totan, L. (2013). Econometric modeling of banking exclusion. Romanian Statistical Review, 61 (3), 50-54.

16. Burgess, R., \& Pande, R. (2005). Do Rural Banks Matter? Evidence from the Indian Social Banking Experiment. American Economic Review, 95(3), 780-795. https://doi. org/ 10.1257/0002828054201242

17. Chakrabarty, K. (2011). Financial Inclusion and Banks: Issues and Perspectives. Address at the FICCI (Federation of Indian Chambers of Commerce \& Industry) - UNDP (The United Nations Development Programme) Seminar on "Financial Inclusion: Partnership between Banks, MFIs and Communities", New Delhi, 14 October 2011. 
18. Chandwani, R., \& Kulkarni, V. (2018). Role of Intermediaries in Providing Financial Access: Current and Future Research Trends. In Dwivedi Y. et al. (eds). Emerging Markets from a Multidisciplinary Perspective (pp. 27-35), Springer, Cham.

19. Chauvet, L., \& Jacolin, L. (2017). Financial Inclusion, Bank Concentration, and Firm Performance. World Development, 97(C), 1-13.

20. Devlin, J. (2009). An analysis of influences on total financial exclusion. Service Industries Journal, 29(8), 1021-1036. https://doi.org/10.1080/02642060902764160

21. Diniz, E., Birochi, R., \& Pozzebon, M. (2011). Triggers and barriers to financial inclusion: The use of ICT-based branchless banking in an Amazon county. Electronic Comerce Research and Applications, 11 (5), 484-494.

22. Dupas, P., Karlan, D., Robinson, J., \& Ubfal, D. (2018). Banking the Unbanked? Evidence from Three Countries. American Economic Journal: Applied Economics, 10(2), 257-97.

23. Fernández, S., Llanes, M., López-Moctezuma, C., Rojas, J., \& Tuesta, D. (2014). Inclusión financiera y el papel de la banca móvil en Colombia: desarrollos y potencialidades. Documento de Trabajo, № 14/01, Madrid: BBVA Research.

24. García, N., Grifoni, A., López, J. C., \& Mejía, M. (2013). La educación financiera en América Latina y el Caribe. Situación actual y perspectivas. Serie Políticas Públicas y Transformación Productiva, 12, Caracas: CAF. http://scioteca.caf.com/ handle/123456789/379

25. Ghosh, M., \& Dixit, R. (2014). Financial Inclusion for Inclusive Growth of India a Study of Indian States. International Journal of Business Management and Research, 3(1), 147-156.

26. Hannig, A., \& Jansen, S. (2010). Financial Inclusion and Financial Stability: Current Policy Issues. ADBI Working Paper 259. Tokyo: Asian Development Bank Institute. https://www.adb.org/sites/default/files/publication/156114/adbi-wp259.pdf.

27. Instituto Nacional de Estadística e Informática (INEI). (2019). Principales indicadores macroeconómicos. Lima: INEI. https://www.inei.gob.pe/estadisticas/indice-tematico/ producto-bruto-interno-por-departamentos-9089/.

28. Instituto Nacional de Estadística e informática (2018a). Evolución de la pobreza monetaria 2007-2017. INEI: Lima. https://www.inei.gob.pe/media/cifras_de_pobreza/ informe_tecnico_pobreza_monetaria_2007-2017.pdf

29. Instituto Nacional de Estadística e Informática (2018b). Telecomunicaciones. INEI: Lima. https://www.inei.gob.pe/media/MenuRecursivo/publicaciones_digitales/Est/ Lib1483/cap21/cap21.htm

30. Instituto Nacional de Estadística e Informática (2018c). Analfabetismo y alfabetismo. INEI: Lima. https://www1.inei.gob.pe/estadisticas/indice-tematico/ analfabetismo-y-alfabetismo-8036/

31. International Labour Organization (ILO). (2016). Role of Finance in Driving Formalization of Informal Enterprises. Geneva: ILO. https://www.ilo.org/wcmsp5/groups/public/...ed_emp/_.-emp_ent/_.-ifp_seed/documents/publication/ wcms 533200.pdf. 
32. Iqbal, B. A., \& Sami, S. (2017). Role of banks in financial inclusion in India. Contaduría y Administración, 62 (2), 644-656. http://dx.doi.org/10.1016/j.cya.2017.01.007

33. Jaramillo, M., C. Aparicio, \& B. Cevallos. (2013). Qué factores explican las diferencias en el acceso al sistema financiero?: evidencia a nivel de hogares en el Perú. Documento de Trabajo/03/2018, Lima: SBS.

34. Kabakova, O., \& Plaksenkov, E. (2018). Analysis of factors affecting financial inclusion: Ecosystem view. Journal of Business Research, 89(C), 198-205.

35. Karpowicz, I. (2016). Financial Inclusion, Growth and Inequality: A Model Application to Colombia. Journal of Banking and Financial Economics, 2(6), 68-89.

36. Kim, J. H. (2016). A Study on the Effect of Financial Inclusion on the Relationship Between Income Inequality and Economic Growth. Emerging Markets Finance and Trade, 52(2), 498-512.

37. Klein, M., \& Mayer, C. 2011. Mobile banking and financial inclusion: The regulatory lessons. Policy Research working paper; no. WPS 5664. Washington, D.C.: World Bank.

38. Kodan, A., \& Chhikara, K. (2013). A Theoretical and Quantitative Analysis of Financial Inclusion and Economic Growth. Management and Labour Studies, 38(1-2), 103-133.

39. Kumar, N. (2013). Financial inclusion and its determinants: evidence from India. Journal of Financial Economic Policy, 5(1), 4-19.

40. Kumar, A., Pal, R., \& Pal, R. (2018). Usage of formal financial services in India: Demand barriers or supply constraints? Economic Modelling, 80(1), 244-259.

41. Léon, F., \& Zins, A. (2020). Regional foreign banks and financial inclusion: Evidence from Africa. Economic Modelling, 84, 102-116.

42. Lopez, T., \& Winkler, A. (2017). The challenge of rural financial inclusion-evidence from microfinance. Applied Economics, 50(14), 1555-1577.

43. Mader, P. (2017). Contesting financial inclusion. Development and Change, 49(2), 461-483.

44. Mas, I., \& Almazán, M. (2011). Banking the Poor through Everyday Stores. Innovations, 6(1), 119-128.

45. Ministerio de la Producción (PRODUCE). (2020). Estadística MIPYME. Lima: PRODUCE. http://ogeiee.produce.gob.pe/index.php/shortcode/estadistica-oee/ estadisticas-mipyme

46. Ministerio de Educación. (2020). Estadísticas de la calidad Educativa. Lima: MINEDU. http://escale.minedu.gob.pe/tendencias

47. Mushtaq, R., \& Bruneau, C. (2019). Microfinance, financial inclusion and ICT: Implications for poverty and inequality. Technology in Society, 59.

48. Neaime, S., \& Gaysset, I. (2018). Financial inclusion and stability in MENA: Evidence from poverty and inequality. Finance Research Letters, 24, 230-237.

49. Owen, L., \& Pereira, J. (2016). Bank Concentration, Competition, and Financial Inclusion (September 8, 2016). https://ssrn.com/abstract $=2836521$. 
50. Ozili, P. (2018). Impact of Digital Finance on Financial Inclusion and Stability. Borsa Istanbul Review, 18(4), 329-340.

51. Park, C.-Y., \& Mercado, R. (2018). Financial Inclusion, Poverty, And Income Inequality. The Singapore Economic Review, 63(01), 185-206.

52. Pizarro Aranguren, L., \& Caballero Muñiz, R. (2009). Acceso al sistema financiero y banca concentrada: isacrificando corderos por leones? IUS ET VERITAS, 19(38), 96-109.

53. Rajeev, M., \& Vani, B. (2017). Financial Access of the Urban Poor in India. A Story of Exclusion. New Delhi: Springer India.

54. Sarma, M. (2008). Index of financial inclusion. Indian Council for Research on International Economic Relations, Working Paper No 215.

55. Sarma, M., \& Pais, J. (2011). Financial Inclusion and Development. Journal of International and Development, 23(5), 613-628.

56. Sharma, D. (2016). Nexus between financial inclusion and economic growth: Evidence from the emerging Indian economy, Journal of Financial Economic Policy, 8(1), 13-36.

57. Schmied, J., \& Marr, A. (2016). Financial inclusion and poverty: The case of Peru. Regional and Sectoral Economic Studies, 16(2), 29-43.

58. Seng, K. (2019). The Poverty-Reducing Effects of Financial Inclusion: Evidence from Cambodia. MPRA Paper 95726.

59. Shihadeh, H., Hannon, A., Guan, J., Haq, I., \& Wang, X. (2018). Does financial inclusion improve the banks' performance? Evidence from Jordan. In J. W. Kensinger (Ed.), Global tensions in financial markets (pp. 117-138), Bradford: Emerald Publishing Limited.

60. Sinja, B., Cull, R., Gine, X., Sven, H., \& Heitmann, S. (2018). Banking with Agents: Experimental Evidence from Senegal (April 19, 2018). World Bank Policy Research Working Paper No. 8417. https://ssrn.com/abstract=3165809

61. Sotomayor, N., Talledo, J., \& Wong, S. (2018). Determinants of financial inclusion in Peru: Recent Evidence from the Demand Side. DT/06, Lima: SBS.

62. Soumaré, I., Tchana, F., \& Kengne, T. (2016). Analysis of the determinants of financial inclusion in Central and West Africa. Transnational Corporations Review, 8(4), 231-249.

63. Stiglitz, J. E., \& Weiss, A. (1981). Credit rationing in markets with imperfect information. The American Economic Review, 71 (3), 393-410

64. Superintendencia de Banca, Seguros y AFP (SBS). (2014). Perú: indicadores de inclusión financiera de los sistemas financiero, de seguros y de pensiones. Lima: SBS. https:// intranet2.sbs.gob.pe/estadistica/financiera/2014/Diciembre/CIIF-0001-di2014.PDF

65. Superintendencia de Banca, Seguros y AFP (SBS). (2017). Perú: indicadores de inclusión financiera de los sistemas financiero, de seguros y de pensiones. Lima: SBS. https:// intranet2.sbs.gob.pe/estadistica/financiera/2017/Diciembre/CIIF-0001-di2017.PDF

66. Superintendencia de Banca, Seguros y AFP (SBS). (2019). Información Estadística de Banca Múltiple. Lima: SBS. https://www.sbs.gob.pe/app/stats/ EstadisticaBoletinEstadistico.asp? $\mathrm{p}=1$ 
67. Talledo, J. (2015). Access to and use of financial services: evidence from Peru. Journal of Financial Issues SBS, 11(1), 1-49.

68. Thoene, U., \& Turriago-Hoyos, A. (2017). Financial inclusion in Colombia: A scoping literature review. Intagible Capital, 13(3), 582-614.

69. Vega, M. (2017). Retail payments innovations in Peru: Modelo Peru and financial inclusion. Journal of Payments Strategy EO Systems, 10(4), 343-351.

70. Zins, A., \& Weill, L. (2016). The determinants of financial inclusion in Africa. Review of Development Finance, 6(1), 46-57.

71. Wang, X., \& Guan, J. (2017). Financial inclusion: measurement, spatial effects and influencing factors. Applied Economics, 49(18), 1-12.

72. Wang'oo, E. (2008). The relationship between financial inclusion and economic development in Kenya. http://erepository.uonbi.ac.ke/handle/11295/63345

73. Wentzel, J. P., Diatha, K. S., \& Yadavalli, V. S. S. (2016). An investigation into factors impacting financial exclusion at the bottom of the pyramid in South Africa. Development Southern Africa, 33(2), 1-12.

74. World Bank. (2000). World Development Report 2000/2001: Attacking Poverty. Washington: Oxford University Press.

75. World Bank. (2019). Financial Inclusion on the Rise, But Gaps Remain, Global Findex Database Shows. World Bank: Washington D. C. https:/www.bancomun dial.org/es/news/press-release/2018/04/19/financial-inclusion-on-the-rise-but-gaps -remain-global-findex-database-shows. 
Guillermo Boitano $•$ Deyvi Franco Abanto

\section{ANNEXES}

\section{Annex 1: Financial Inclusion Index by Department, 2010-2017}

\begin{tabular}{|c|c|c|c|c|c|c|c|c|}
\hline Departments & 2010 & 2011 & 2012 & 2013 & 2014 & 2015 & 2016 & 2017 \\
\hline Amazonas & 0.064 & 0.097 & 0.082 & 0.087 & 0.097 & 0.077 & 0.084 & 0.094 \\
\hline Áncash & 0.185 & 0.196 & 0.195 & 0.202 & 0.191 & 0.183 & 0.180 & 0.172 \\
\hline Apurímac & 0.146 & 0.191 & 0.213 & 0.240 & 0.224 & 0.246 & 0.169 & 0.181 \\
\hline Arequipa & 0.328 & 0.450 & 0.462 & 0.474 & 0.458 & 0.447 & 0.439 & 0.442 \\
\hline Ayacucho & 0.109 & 0.138 & 0.142 & 0.119 & 0.127 & 0.117 & 0.147 & 0.156 \\
\hline Cajamarca & 0.125 & 0.169 & 0.156 & 0.167 & 0.160 & 0.158 & 0.182 & 0.182 \\
\hline Cusco & 0.220 & 0.255 & 0.276 & 0.272 & 0.280 & 0.313 & 0.336 & 0.327 \\
\hline Huancavelica & 0.013 & 0.026 & 0.021 & 0.023 & 0.000 & 0.031 & 0.031 & 0.036 \\
\hline Huánuco & 0.084 & 0.114 & 0.125 & 0.149 & 0.144 & 0.125 & 0.135 & 0.130 \\
\hline Ica & 0.289 & 0.337 & 0.363 & 0.369 & 0.363 & 0.350 & 0.366 & 0.354 \\
\hline Junín & 0.220 & 0.275 & 0.302 & 0.313 & 0.298 & 0.267 & 0.296 & 0.304 \\
\hline La Libertad & 0.276 & 0.341 & 0.358 & 0.346 & 0.325 & 0.328 & 0.339 & 0.336 \\
\hline Lambayeque & 0.311 & 0.391 & 0.391 & 0.395 & 0.374 & 0.360 & 0.367 & 0.358 \\
\hline Loreto & 0.083 & 0.124 & 0.121 & 0.116 & 0.113 & 0.103 & 0.114 & 0.095 \\
\hline Madre de Dios & 0.296 & 0.309 & 0.346 & 0.319 & 0.322 & 0.277 & 0.274 & 0.300 \\
\hline Moquegua & 0.239 & 0.262 & 0.257 & 0.251 & 0.272 & 0.277 & 0.288 & 0.291 \\
\hline Pasco & 0.106 & 0.113 & 0.130 & 0.138 & 0.126 & 0.114 & 0.103 & 0.114 \\
\hline Piura & 0.243 & 0.328 & 0.343 & 0.336 & 0.310 & 0.319 & 0.348 & 0.355 \\
\hline Puno & 0.107 & 0.150 & 0.183 & 0.192 & 0.201 & 0.182 & 0.190 & 0.195 \\
\hline San Martín & 0.200 & 0.225 & 0.252 & 0.255 & 0.217 & 0.185 & 0.200 & 0.211 \\
\hline Tacna & 0.312 & 0.412 & 0.406 & 0.405 & 0.398 & 0.381 & 0.399 & 0.406 \\
\hline Tumbes & 0.272 & 0.307 & 0.299 & 0.284 & 0.269 & 0.242 & 0.264 & 0.276 \\
\hline Ucayali & 0.156 & 0.184 & 0.230 & 0.237 & 0.254 & 0.218 & 0.228 & 0.226 \\
\hline
\end{tabular}

Source: authors' elaboration. 


\section{Annex 2: Financial Inclusion Index and GDP per capita, 2009}

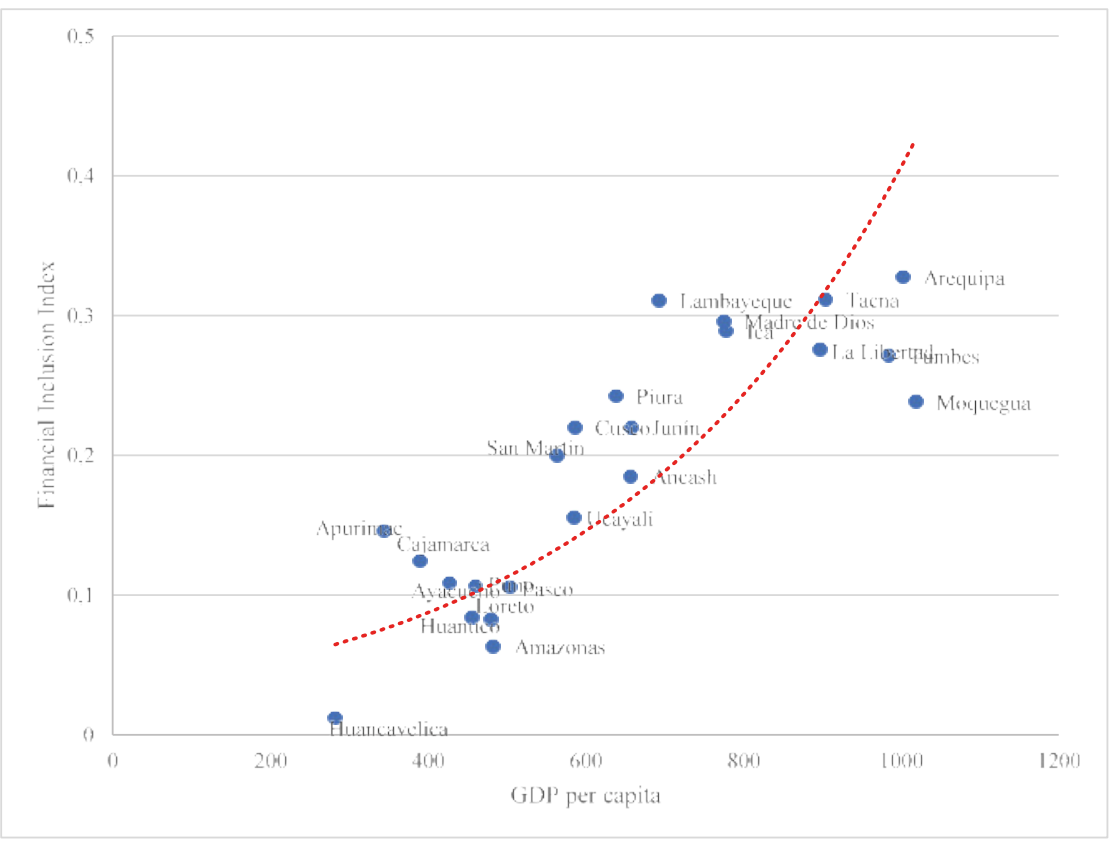

Source: authors' elaboration based on INEI (2019) and SBS (2014) information.

Note: The calculated Sarma index (formulated through three factors: penetration, availability, and use of financial services) matches the results shown on the SBS financial inclusion report (2014). Huancavelica, Amazonas, and Huánuco are the regions with the lowest financial inclusion index (percentages vary from $6 \%$ to $11 \%$ ). 


\section{Annex 3: Financial Inclusion Index and GDP per capita, 2017}

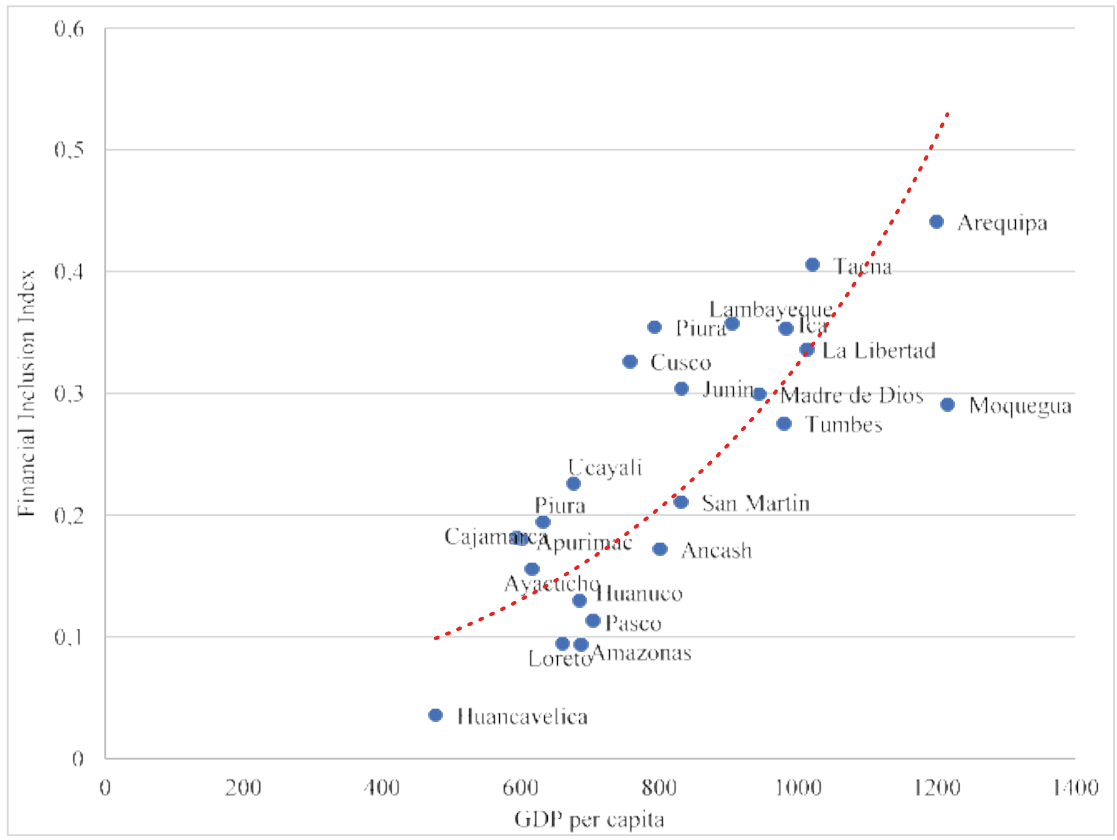

Source: authors' elaboration based on INEI (2018) and SBS information (2017).

Note: The calculated Sarma index in 2017 shows a variation with respect to 2010 due to a change in the three regions with the lowest financial inclusion: Huánuco leaves the group and is replaced by Loreto. These results are comparable with data obtained by the SBS in the same year (2017). 


\section{Annex 4: The Model}

\begin{tabular}{|c|c|}
\hline \multirow{2}{*}{ Variables } & $\begin{array}{l}\text { Dependent variable: Financial Inclusion Index } \\
\text { (Sarma, 2008) }\end{array}$ \\
\hline & $\begin{array}{c}(\mathrm{GMM}) \\
(5)\end{array}$ \\
\hline \multirow{2}{*}{ Banking Concentration (HHI) } & $-0.235^{* *}$ \\
\hline & $(0.111)$ \\
\hline \multirow{2}{*}{ Unsatisfied Basic Needs (2 or more) } & $-0.0722^{*}$ \\
\hline & $(0.038)$ \\
\hline \multirow{2}{*}{$\begin{array}{l}\text { Mobile Broadband Subscription (\# } \\
\text { Smartphones) }\end{array}$} & $0.318^{* * *}$ \\
\hline & $(0.105)$ \\
\hline \multirow{2}{*}{ Lower Middle-Income S/. 400 - S/. 750} & $0.159^{* *}$ \\
\hline & $(0.067)$ \\
\hline \multirow{2}{*}{ Upper Middle-Income S/. 750 - S/. 1500} & 0.0917 \\
\hline & $(0.093)$ \\
\hline \multirow{2}{*}{ Illiteracy Rate } & -0.0042 \\
\hline & $(0.009)$ \\
\hline \multirow{2}{*}{ Secondary Education } & 0.00974 \\
\hline & $(0.174)$ \\
\hline \multirow{2}{*}{ Informal Micro and Small Enterprises } & -0.1 \\
\hline & $(0.051)$ \\
\hline \multirow{2}{*}{$\begin{array}{l}\text { Mobile Banking Applications (0: before and 1: } \\
\text { after) }\end{array}$} & $-0.130^{* * *}$ \\
\hline & $(0.041)$ \\
\hline \multirow{2}{*}{ Constant } & $0.336^{*}$ \\
\hline & $(0.198)$ \\
\hline $\mathrm{N}$ & 184 \\
\hline Hansen p-value & 0.3967 \\
\hline
\end{tabular}

Note: The list of instruments for the generalized method of moments (GMM) is limited to the use of ten instruments (as described in Equation 3). P-values of the Hansen test of over-identifying restrictions (to test the null hypothesis that the instruments are valid) are reported. In parentheses, the standard errors are shown.

${ }^{*} \mathrm{p}<0.05,{ }^{* *} \mathrm{p}<0.01,{ }^{* * *} \mathrm{p}<0.001$

Source: authors' elaboration. 